Jurnal Farmamedika Vol 4, No. 1 Juni 2019

\title{
AKTIVITAS ANTIOKSIDAN EKSTRAK ETANOL 70\% DAN INFUSA DAUN KECIPIR (Psophocarpus tetragonolobus (L.) DC.) DENGAN METODE PERENDAMAN RADIKAL BEBAS
}

\author{
Eem Masaenah $^{1 *}$, Anna P. Roswiem², Devina Putri ${ }^{3}$ \\ 1. Program Studi S1 Farmasi, Sekolah Tinggi Teknologi Industri dan Farmasi Bogor \\ 2. Program Studi S1 Farmasi, Sekolah Tinggi Teknologi Industri dan Farmasi Bogor \\ 3. Mahasiswa Program Studi S1 Farmasi Sekolah Tinggi Teknologi Industri dan Farmasi Bogor \\ Korespondensi: "masaenaheem@gmail.com, eem@sttif.ac.id
}

\begin{abstract}
ABSTRAK
Daun kecipir (Psophocarpus tetragonolobus (L.) DC.) telah diketahui mengandung senyawa vitamin $\mathrm{C}$ yang dapat berkhasiat sebagai antioksidan. Penelitian ini bertujuan untuk mengetahui kandungan metabolit sekunder dan menguji aktivitas antioksidan ekstrak etanol $70 \%$ dan infusa daun kecipir (Psophocarpus tetragonolobus (L.) DC.) dengan metode peredaman radikal bebas menggunakan DPPH. Ekstrak etanol 70\% daun kecipir (Psophocarpus tetragonolobus (L.) DC.) dibuat dengan deret konsentrasi 10, 15, 20, 25, 30 ppm dan infusa daun kecipir (Psophocarpus tetragonolobus (L.) DC.) dengan deret konsentrasi 75, 100, 125, 150, 175 ppm. Kemudian ekstrak dan infusa dilarutkan dengan metanol pro analisis dan DPPH. Diukur absorbansinya menggunakan Spektrofotometer UV-Vis pada panjang gelombang $517 \mathrm{~nm}$. Ekstrak etanol $70 \%$ daun kecipir (Psophocarpus tetragonolobus (L.) DC.) mengandung flavonoid, saponin, tanin, steroid dan infusa daun kecipir (Psophocarpus tetragonolobus (L.) DC.) mengandung flavonoid, saponin, dan tanin. Ekstrak etanol 70\% daun kecipir (Psophocarpus tetragonolobus (L.) DC.) memiliki aktivitas antioksidan dengan nilai $I C_{50}$ sebesar $22,12 \mathrm{ppm}$ (sangat kuat) dan infusa daun kecipir (Psophocarpus tetragonolobus (L.) DC.) sebesar 167,03 ppm (lemah) serta vitamin C sebagai kontrol positif sebesar 6,82 ppm (sangat kuat).
\end{abstract}

Kata kunci: Antioksidan, DPPH, Ekstrak, Infusa, Psophocarpus tetragonolobus (L.) DC.).

\begin{abstract}
Winged leaf (Psophocarpus tetragonolobus (L.) DC.) has been known to contain vitamin C compounds which can be efficacious as antioxidants. The aims of this study was determine the secondary metabolites contained in $70 \%$ ethanol extract and winged leaf (Psophocarpus tetragonolobus (L.) DC) infusion and to test the antioxidant activity of $70 \%$ ethanol extract and winged leaf infusion (Psophocarpus tetragonolobus (L.) DC). ) with the free radical reduction method using DPPH. Ethanol extract of $70 \%$ winged leaf (Psophocarpus tetragonolobus (L.) DC.) was made with a series of concentrations of 10, 15, 20, 25, $30 \mathrm{ppm}$ and infusion of winged leaf (Psophocarpus tetragonolobus (L.) DC) with a series of concentrations of 75, 100, 125, 150, 175 ppm are both dissolved with methanol pro analysis and DPPH, then their absorbance is measured using a UV-Vis spectrophotometer at a wavelength of $517 \mathrm{~nm}$. Ethanol extract of $70 \%$ winged leaf (Psophocarpus tetragonolobus (L.) DC.) Contains flavonoid, saponin, tannin, steroids and winged leaf infusion (Psophocarpus tetragonolobus (L.) DC) contains flavonoid, saponin, tannin. Ethanol extract of $70 \%$ winged leaf (Psophocarpus tetragonolobus (L.) DC.) Has antioxidant activity with $I C_{50}$ value of $22.12 \mathrm{ppm}$ (very strong) and winged leaf infusion (Psophocarpus tetragonolobus (L.) DC.) of $167.03 \mathrm{ppm}$ (weak) and vitamin $\mathrm{C}$ as a positive control of $6.82 \mathrm{ppm}$ (very strong).
\end{abstract}

Keywords: Antioxidant, DPPH, Extract, Infusion, Psophocarpus tetragonolobus (L.) DC. 


\section{PENDAHULUAN}

Antioksidan adalah senyawa yang dapat mengurangi, menahan dan mencegah proses oksidasi dengan menyumbang satu atau lebih elektron pada radikal bebas, sehingga radikal bebas dapat diredam. Tubuh manusia memiliki antioksidan yang disebut antioksidan endogen termasuk enzim intraseluler seperti superoksida dismutase [1]. Radikal bebas merupakan atom atau gugus atom yang memiliki satu atau lebih elektron tidak berpasangan sehingga bersifat sangat reaktif. Radikal bebas secara terus menerus terbentuk di dalam tubuh. Jumlah sangat banyak dapat berpotensi menonaktifkan berbagai enzim, mengoksidasi lemak, dan mengganggu DNA tubuh sehingga terjadi mutasi sel yang merupakan awal timbulnya kanker dan dapat menyebabkan penuaan dini. Reaksi rantai akan berhenti bila radikal bebas itu diredam. Oleh karena itu diperlukan senyawa yang dapat meredam efek negatif dari radikal bebas ini yang disebut dengan antioksidan [2].

Indonesia dikenal dengan keragaman sumber daya genetik tanaman yang sangat banyak. Salah satu diantaranya ialah kecipir (Psophocarpus tetragonolobus (L.) DC.) yang termasuk dalam keluarga Fabaceae (kacangkacangan). Kecipir tidak digunakan secara luas hanya sebagai tanaman sayuran tradisional. Pada umumnya kecipir ditanam di pekarangan rumah dan digunakan sebagai sayuran di daerah-daerah tropis. Penelitian tanaman kecipir telah dilakukan oleh Badan Penelitian Tanaman Sayuran di Bandung pada tahun 2013. Dari hasil penelitian tersebut daun kecipir mengandung banyak vitamin diantaranya vitamin C 14,5-128 mg dan vitamin E 3,5 mg dalam $100 \mathrm{~g}$ daun kecipir [3].

Penelitian sebelumnya, ekstrak etanol 96\% daun kecipir mengandung metabolit sekunder flavonoid, saponin, tanin, steroid dan triterpenoidserta memiliki nilai $I C_{50}$ sebesar 60,34 ppm (kuat) [4].

Berdasarkan hasil penelitian diatas, maka peneliti ingin menguji apakah ekstrak etanol $70 \%$ dan infusa daun kecipir memiliki aktivitas antioksidan yang lebih baik.

Penelitian ini bertujuan untuk mengetahui kandungan senyawa metabolit sekunder dan menentukan aktivitas antioksidan ekstrak etanol $70 \%$ dan infusa daun kecipir.

\section{METODE PENELITIAN Alat dan Bahan}

Peralatan yang digunakan adalah timbangan digital (ACIS), rotary evaporator (IKA RV 10 basic), waterbath, spektrofotometer UV-Vis (Shimazdu Uv mini-1240), cawan, blender (PHILIPS HR 2116), oven (Memmert), bunsen, kaki tiga, botol semprot, dan alat-alat gelas.

Bahan-bahan yang digunakan adalah etanol 70 $\%$, serbuk simplisia daun kecipir, vitamin $\mathrm{C}$, Aquadest, $\mathrm{HCl}$, pereaksi Mayer, pereaksi Wagner, pereaksi Dragendorff, $\mathrm{FeCl}_{3}, \mathrm{CHCl}_{3}$, $\mathrm{H}_{2} \mathrm{SO}_{4}, \mathrm{NH}_{3}$, metanol p.a, logam $\mathrm{Mg}$, etanol $96 \%, \quad\left(\mathrm{C}_{2} \mathrm{H}_{5}\right) 2 \mathrm{O}, \quad$ dan 1,1-difenil-2pikrilhidrazil.

\section{Prosedur Penelitian \\ Pembuatan Simplisia}

Daun kecipir (Psophocarpus tetragonolobus (L.) DC.) diambil pada pagi hari dan daun yang dipetik yaitu 3 helai dari pucuk. Disortasi basah, dicuci dan dibersihkan menggunakan air mengalir. Setelah bersih, ditiriskan dengan cara diangin-anginkan didalam ruangan selama 1 hari. Selanjutnya dirajang dan dilakukan pengeringan dengan cara diangin-anginkan selama 10 hari. Simplisia kering disortasi dan dihaluskan dengan blender serta diayak dengan ayakan no. 40 mesh.

\section{Penetapan Kadar Air}

Penetepan kadar air dilakukan dengan cara memasukkan cawan kosong ke dalam oven hingga bobot cawan konstan. Selanjutnya ke dalam cawan dimasukkan serbuk simplisia sebanyak 5g. Cawan yang berisi simplisia dimaksukkan ke dalam oven pada suhu 100$105^{\circ} \mathrm{C}$, setelah satu jam, sampel kering didinginkan dalam desikator selama 15 menit, setelah dingin cawan ditimbang. Pengeringan di dalam oven dilakukan berulang hingga diperoleh bobot konstan. Kemudian dihitung kadar air simplisia daun kecipir menggunakan rumus:

Kadar air $(\%)=\frac{a-b}{a} \times 100 \%$

$\mathrm{a}=$ bobot sampel sebelum pemanasan $(\mathrm{g})$

$\mathrm{b}=$ bobot sampel setelah pemanasan $(\mathrm{g})$

\section{Pembuatan Ekstrak Etanol $\mathbf{7 0 \%}$ Daun Kecipir}

Serbuk simplisia daun kecipir sebanyak 200 gram dimaserasi dengan etanol $70 \%$ selama $3 \times 24$ jam. Tiap 1×24 jam dilakukan penyaringan dan diremaserasi. Kemudian, filtrat dijadikan satu dan dipekatkan menggunakan rotary evaporator setelah itu di waterbath sampai diperoleh ekstrak kental. Ekstrak kental yang diperoleh ditimbang 
kemudian nilai persentase rendemen dihitung menggunakan rumus berikut :

\section{Pembuatan Infusa Daun Kecipir}

Serbuk simplisia daun kecipir ditimbang sebanyak 5 gram dipanaskan dengan air $50 \mathrm{~mL}$

\section{Penapisan Fitokimia Ekstrak Etanol \& Infusa Daun Kecipir}

i. Identifikasi alkaloid

Sebanyak masing-masing $5 \mathrm{~mL}$ filtrat ditambahkan dengan beberapa tets asam sulfat $2 \mathrm{~N}$ lalu diuji dengan pereaksi Mayer, Wagner, dan Dragendorff. Hasil adanya senyawa alkaloid ditandai dengan terbentuknya endapan putih (Pereaksi Mayer), endapan kuning kecokelatan (Pereaksi Wagner) dan endapan merah jingga (Pereaksi Dragendorff).

ii. Identifikasi flavonoid

Sebanyak masing-masing $5 \mathrm{~mL}$ filtrat ditambahkan $0,5 \quad \mathrm{mg}$ serbuk $\mathrm{Mg}$ ditambahkan $1 \mathrm{~mL} \mathrm{HCl}$ Pekat dan $1 \mathrm{~mL}$ amil alkohol. Kemudian campuran dikocok kuat, munculnya warna merah atau kuning positif menunjukkan adanya flavonoid.

iii. Identifikasi saponin

\section{Uji Aktivitas Antioksidan Ekstrak Etanol 70\% dan Infusa Daun Kecipir}

1. Pembuatan larutan DPPH

Sejumlah $5 \mathrm{mg}$ DPPH dilarutkan dengan 50 $\mathrm{mL}$ metanol p.a hingga didapatkan konsentrasi $100 \mathrm{ppm}$.

2. Pembuatan larutan blanko

Sejumlah $1 \mathrm{~mL}$ metanol p.a dipipet dimasukkan ke tabung reaksi ditambahkan 1 $\mathrm{mL}$ DPPH dan $2 \mathrm{~mL}$ metanol dikocok hingga homogen. Kemudian didiamkan selama 30 menit dalam ruangan gelap dan diukur absorbansinya.

3. Optimasi panjang gelombang DPPH

Larutan DPPH konsentrasi 100 ppm ditentukan spektrum serapan menggunakan spektrofotometer UV-Vis pada panjang gelombang 400-800 $\mathrm{nm}$ dan ditentukan panjang gelombang maksimumnya.

4. Pembuatan larutan sampel

Ekstrak etanol $70 \%$ dibuat larutan dengan konsentrasi 1000 ppm dengan $100 \mathrm{mg}$ ekstrak dan $100 \mathrm{~mL}$ metanol p.a.

Infusa daun kecipir dengan konsentrasi 100.000 ppm dengan 5 gram serbuk simplisia dan $50 \mathrm{~mL}$ air $90^{\circ} \mathrm{C}$ disaring dan mendapatkan filtrat sebanyak $50 \mathrm{~mL}$.

\section{$\frac{\text { Bobot ekstrak kental }}{\text { Bobot simplisia yang diekstraksi }} \times 100 \%$}

dengan suhu $90^{\circ} \mathrm{C}$ selama 15 menit kemudian disaring dan dicukupkan dengan air panas hingga $50 \mathrm{~mL}$

Sebanyak masing-masing $10 \mathrm{~mL}$ filtrat dikocok selama 10 detik jika terbentuk buih 1-10 $\mathrm{cm}$ yang stabil tidak kurang dari 10 menit dan tidak hilang dengan penambahan 1 tetes $\mathrm{HCl} 2 \mathrm{~N}$ maka sampel positif mengandung saponin.

iv. Identifikasi tannin

Sebanyak masing-masing $5 \mathrm{~mL}$ filtrat ditambahkan dengan air hingga tidak berwarna. Kemudian diambil $2 \mathrm{~mL}$ dan ditetesi 1-2 tetes pereaksi $\mathrm{FeCl}_{2}$. Hasil uji positif ditandai dengan munculnya warna hijau atau biru kehitaman.

v. Identifikasi steroid dan triterpenoid

Sebanyak masing-masing $5 \mathrm{~mL}$ filtrat ditambahkan $2 \mathrm{~mL} \mathrm{CHCl}$ dalam tabung reaksi lalu ditambahkan 10 tetes asetat anhidrat dan 3 tetes asam sulfat pekat. Reaksi positif ditunjukkan dengan terbentuknya larutan berwarna biru atau hijau untuk steroid serta merah atau ungu untuk triterpenoid.

Masing-masing sampel dibuat larutan deret standar. Larutan ekstrak etanol $70 \%$ dengan konsentrasi 10, 15, 20, 25, dan $30 \mathrm{ppm}$ sedangkan infusa dengan konsentrasi 75 , 100, 125, 150, dan 175 ppm.

5. Pembuatan larutan vitamin C (kontrol positif)

Sejumlah $100 \mathrm{mg}$ vitamin C dilarutkan dalam $100 \mathrm{~mL}$ metanol p.a. kemudian dibuat larutan deret standarnya dengan konsentrasi $2,4,6,8$, dan $10 \mathrm{ppm}$.

6. Pengujian aktivitas antioksidan

Masing-masing larutan dipipet $1 \mathrm{~mL}$ dimasukan ke tabung reaksi dan ditambahkan $1 \mathrm{~mL}$ DPPH dan $2 \mathrm{~mL}$ metanol dikocok hingga homogen, didiamkan selama 30 menit dalam ruangan gelap dan diukur serapannya pada panjang gelombang maximum $517 \mathrm{~nm}$.

\section{Analisis data}

Dihitung Nilai $I C_{50}$ bedasarkan persentase inhibisi terhadap radikal DPPH dari masingmasing konsentrasi sampel dengan rumus:

$$
\text { Inhibisi }=\frac{\text { A blanko }- \text { A sampel }}{\text { A blanko }} \times 100 \%
$$


Setelah didapatkan persentase inhibisi dari masing-masing konsentrasi, kemudian ditentukan persamaan $\mathrm{Y}=\mathrm{a}+\mathrm{bx}$ dengan perhitungan secara regresi linear dimana $x$ adalah konsentrasi dan y adalah persen inhibisi. Aktivitas antioksidan dinyatakan dengan inhibition concentration $50 \% \quad\left(I C_{50}\right)$ yaitu konsentrasi sampel yang dapat meredam radikal bebas DPPH sebanyak 50\%.

\section{HASIL DAN PEMBAHASAN}

\section{Pembuatan Simplisia}

Sampel basah daun kecipir disortasi basah bertujuan untuk memisahkan bagian tanaman yang tidak digunakan, kemudian dicuci dan dibersihkan dari kotoran, debu, dan tanah menggunakan air mengalir. Setelah bersih, ditiriskan dengan cara diangin-anginkan di dalam ruangan selama 1 hari yang bertujuan untuk mencegah proses enzimatis pada daun. Dilakukan perajangan dengan tujuan memudahkan proses pengeringan. Selanjutnya dikeringkan di dalam ruangan selama 10 hari. Simplisia kering dihaluskan dengan blender, dan diayak dengan pengayak ukuran 40 mesh bertujuan untuk menyeragamkan ukuran partikel dan mendapatkan serbuk simplisia yang halus sehingga memudahkan tertariknya metabolit sekunder pada saat proses ekstraksi sehingga proses ekstraksi akan lebih optimal [5].

\section{Hasil Penetapan Kadar Air}

Penetapan kadar air dilakukan dengan metode gravimetri pada suhu $105^{\circ} \mathrm{C}$. Pada simplisia daun kecipir didapatkan nilai kadar air sebesar 2,3\% dan syarat umum kadar air pada daun, yaitu kurang dari 10\% [6]. Hal ini memenuhi syarat ketentuan kadar air untuk daun sehingga simplisia tidak mudah ditumbuhi jamur maupun mikroba dan memiliki umur simpan yang lama.

\section{Hasil Ekstraksi Simplisia}

Sejumlah 200 gram serbuk simplisia daun kecipir diekstraksi dengan cara maserasi dan infusa dibuat dengan serbuk simplisia sebanyak 5 gram. Maserasi dipilih karena merupakan cara ekstraksi yang palingsederhana sedangkan infusa merupakan cara dengan pemanasan pada suhu tertentu dengan cara dan peralatan yang lebih sederhana, sehingga dapat diaplikasi oleh masyarakat. Bobot ekstrak kental etanol 70\% simplisia daun kecipir diperoleh sebesar 18,85 gram dengan nilai rendemen $9,42 \%$.

\section{Hasil Penapisan Fitokimia}

Pada penafisan fitokimia ekstrak etanol $70 \%$ daun kecipir menunjukkan bahwa ekstrak etanol daun kecipir mengandung flavonoid, saponin, tanin, dan steroid. Sedangkan infusa daun kecipir mengandung flavonoid, saponin, dan tanin. Ada perbedaan antara ekstrak etanol $70 \%$ dan infusa dalam kandungan fitokimia ini diduga disebabkan karena perbedaan pelarut yang digunakan antara sampel infusa menggunakan aquadest dan ekstrak menggunakan etanol $70 \%$. Senyawa steroid merupakan senyawa organik lemak yang tidak larut air. Logam magnesium dan $\mathrm{HCl}$ bereaksi membentuk gelembung yang merupakan gas $\mathrm{H}_{2}$. Logam $\mathrm{Mg}$ dan $\mathrm{HCl}$ pekat pada uji ini berfungsi untuk mereduksi inti benzopiron yang terdapat pada struktur flavonoid sehingga terbentuk perubahan warna.

\section{Hasil Pengujian Aktivitas Antioksidan}

Pengujian aktivitas antioksidan dilakukan dengan metode peredaman radikal bebas melalui pengukuran absorbansi menggunakan spektrofotometer UV-Vis. Dipilih untuk metode peredaman radikal bebas karena metode tersebut lebih sederhana, waktu pengujian singkat, serta hanya memerlukan sedikit sampel [7]. Nilai $I C_{50}$ dihitung dengan menggunakan rumus persamaan regresi.

Pengukuran antioksidan dapat dilakukan secara kualitatif dengan adanya perubahan warna pada suatu sampel dari warna ungu menjadi warna kuning. Hal ini terjadi karena elektron radikal bebas DPPH berpasangan dengan atom hidrogen. DPPH merupakan senyawa yang stabil dan hanya bisa diredam oleh antioksidan yang bisa memberikan atom hidrogen, maka semakin banyak gugus hidroksil, semakin tinggi kemampuan suatu senyawa untuk meredam DPPH dan semakin tinggi pula kemampuan senyawa tersebut sebagai antioksidan [8].

Selain secara kualitatif antioksidan juga dapat dilakukan sacara kuantitatif dengan menggunakan alat spektrofotometer UV-Vis. Metode ini akan mendapatkan hasil berupa nilai absorbansi suatu sampel yang selanjutnya dapat dihitung dengan cara regresi linear dengan persentase inhibisi dari masing-masing konsentrasi, kemudian ditentukan persamaan y $=\mathrm{a}+\mathrm{bx}$ dan dinyatakan dengan nilai $\mathrm{IC}_{50}$ (Inhibition Consetration 50\%). Pengujian aktivitas antioksidan secara kuantitatif dilakukan pengukuran absorbansi blanko untuk penentuan nilai panjang gelombang maksimum. Didapatkan panjang gelombang maksimum $517 \mathrm{~nm}$. 
15 Eem Masaenah et al., (Aktivitas Antioksidan Ekstrak Etanol 70\% dan Infusa...)

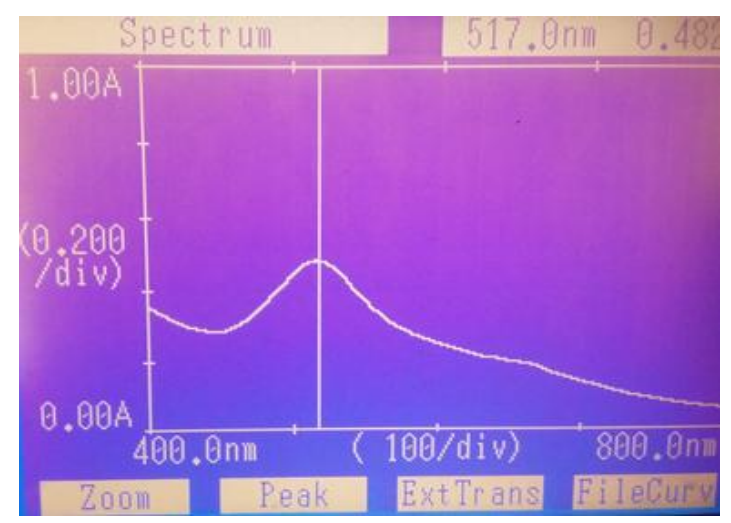

\section{Gambar 1. Panjang Gelombang Maksimum DPPH}

Setelah itu dilakukan pengukuran absorbansi untuk sampel pertama yaitu ekstrak etanol $70 \%$ daun kecipir pada panjang gelombang maximum $517 \mathrm{~nm}$. Kemudian dihitung persentase inhibisinya dan didapatkan kurva regresi linear selanjutnya dihitung aktivitas antioksidannya (nilai $I C_{50}$ ).

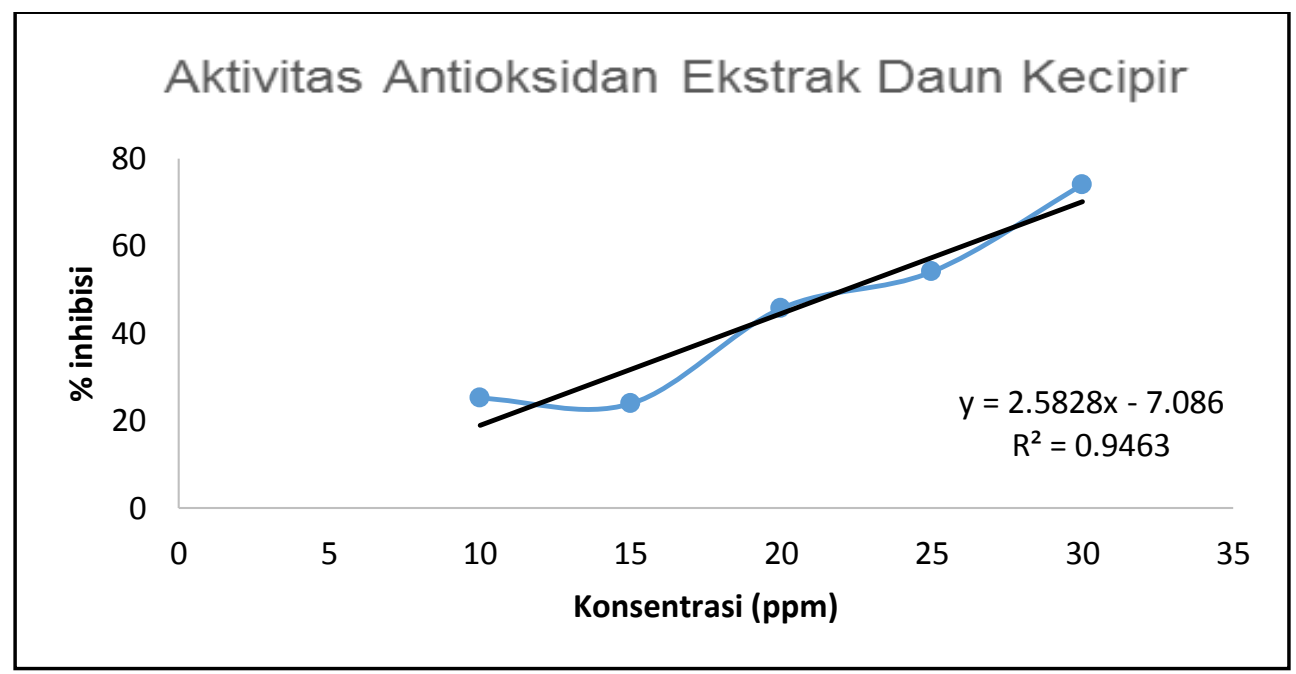

Gambar 2. Grafik Aktivitas Antioksidan Ekstrak Etanol 70\% Daun Kecipir

Penetapan antioksidan yang dilakukan pada ekstrak etanol $70 \%$ daun kecipir mempunyai nilai $\mathrm{IC}_{50} 22,12 \mathrm{ppm}$, termasuk kategori antioksidan sangat kuat [9]. Hasil penelitian ini memiliki nilai $I C_{50}$ lebih kuat (kategori sangat kuat) dibandingkan dengan penelitian Safitri (2018) dengan kategori kuat yaitu sebesar 60,34 ppm. Hal ini diduga disebabkan karena perbedaan wilayah pengambilan bahan sampel karena pertumbuhan dan metabolisme tanaman dipengaruhi oleh keadaan tanah, kondisi perairan dan lingkungan serta intensitas dari matahari pada tanaman tersebut. Selain itu, dapat disebabkan dari konsentrasi pelarut yang digunakan pada penelitian ini berbeda dengan konsentrasi pelarut pada penelitian Safitri (2018), dan juga disebabkan adanya perbedaan kepolaran dari etanolnya.

Hasil pengukuran absorbansi sampel kedua yaitu infusa daun kecipir pada panjang gelombang maximum $517 \mathrm{~nm}$ didapatkan kurva regresi linear dan dihitung aktivitas antioksidan dengan nilai $\mathrm{IC}_{50}$ sebesar $167,03 \mathrm{ppm}$, yang tergolong kategori lemah. 
16 Eem Masaenah et al., (Aktivitas Antioksidan Ekstrak Etanol 70\% dan Infusa...)

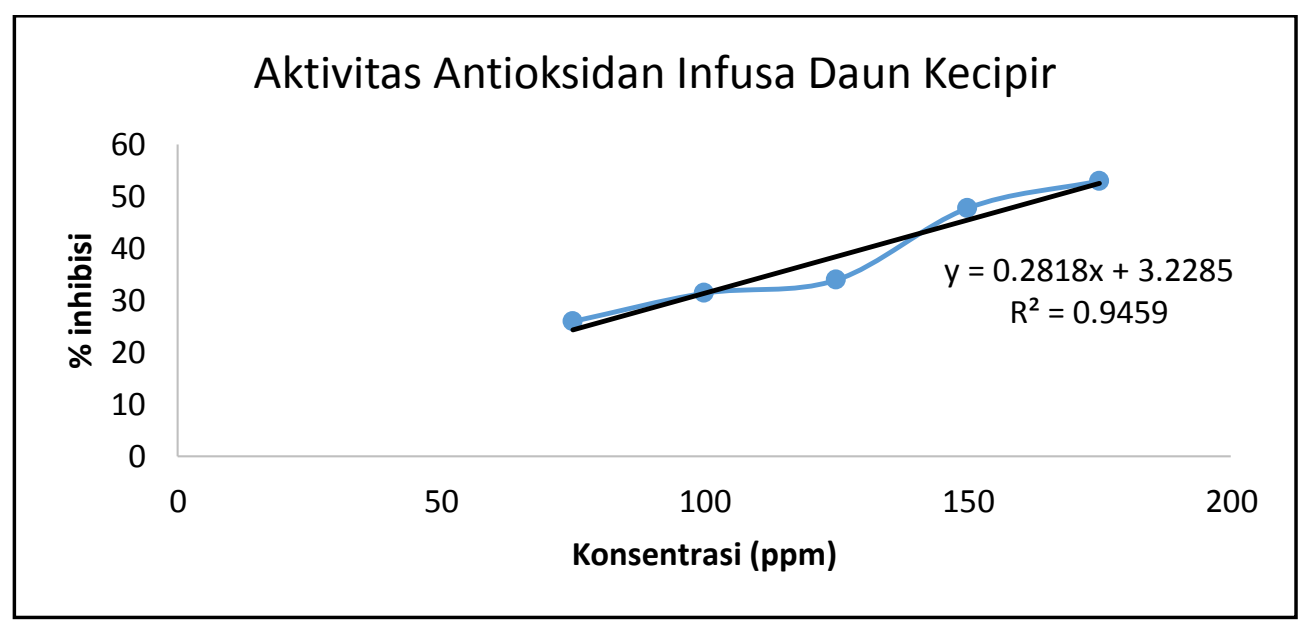

Gambar 3. Grafik Aktivitas Antioksidan Infusa Daun Kecipir

Pengujian antioksidan ini digunakan sampel ekstrak etanol $70 \%$ daun kecipir dan Vitamin $\mathrm{C}$ sebagai kontrol positif yang infusa daun kecipir dan didapatkan data merupakan antioksidan baik. Vitamin $\mathrm{C}$ untuk aktivitas antioksidan serta persen inhibisi membandingkan aktivitas antioksidan dari vitamin $\mathrm{C}$ dapat dilihat pada Gambar 4.

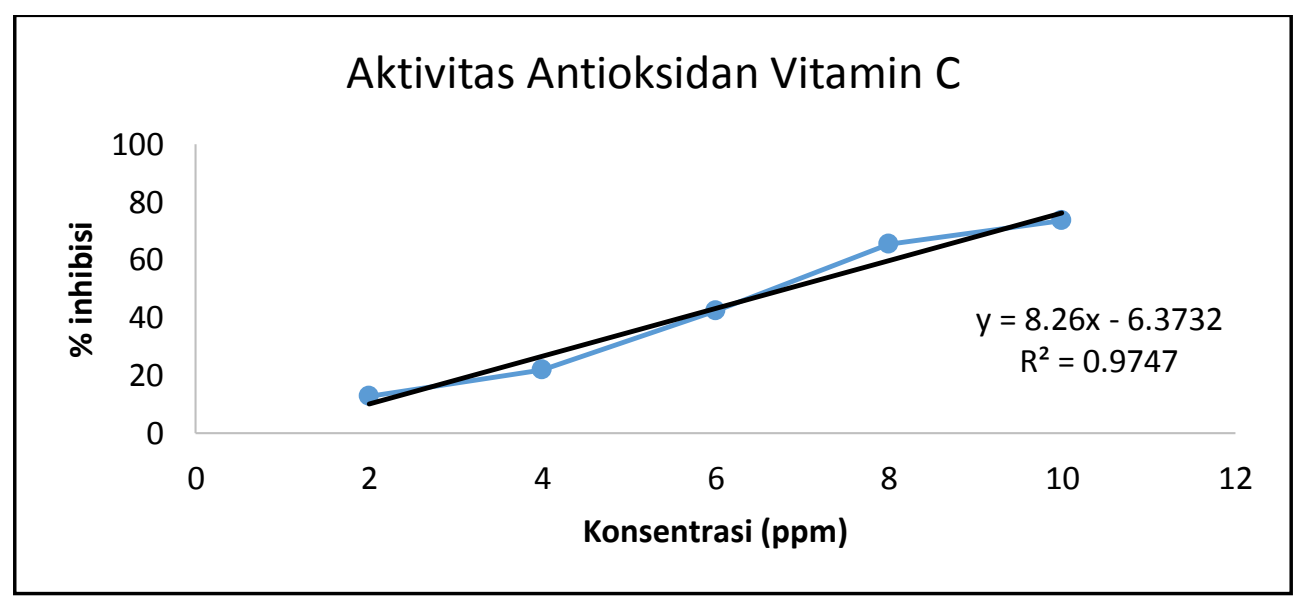

Gambar 4. Grafik Aktivitas Antioksidan Vitamin C

Penetapan antioksidan yang dilakukan 6,82 ppm dan termasuk kedalam kategori pada vitamin $\mathrm{C}$ mempunyai nilai $I C_{50}$ sebesar antioksidan yang sangat kuat.

Tabel 1. NIlai $\mathrm{IC}_{50}$ Sampel Uji dan Kontrol Positif

\begin{tabular}{|c|c|c|}
\hline Sampel & Nilai $I C_{50}(\mathrm{ppm})$ & Kategori [ ] \\
\hline 1. Ekstrak Etanol $70 \%$ Daun Kecipir & 22,12 & Sangat Kuat \\
\hline 2. Infusa Daun Kecipir & 167,03 & Lemah \\
\hline 3. Vitamin $\mathrm{C}$ & 6,82 & Sangat Kuat \\
\hline
\end{tabular}


Hasil $I C_{50}$ yang didapat dari penelitian ini menunjukan bahawa nilai $\mathrm{IC}_{50}$ ekstrak etanol $70 \%$ lebih baik dibandingkan nilai $\mathrm{IC}_{50}$ pada infusa daun kecipir, hal ini diduga disebabkan karena pelarut yang digunakan pada infusa daun kecipir yaitu aquadest dan metode ekstraksi yang digunakan pada penelitian ini berbeda sehingga diduga kurang tertariknya zat aktif pada infusa daun kecipir (Psophocarpus tetragonolobus (L.)DC.). Semakin rendah nilai $I C_{50}$ maka semakin kuat aktivitas antioksidan suatu sampel semakin kuat aktivitas antioksidan suatu sampel [10].

\section{SIMPULAN}

Berdasarkan hasil penelitian yang telah dilakukan dapat disimpulkan bahwa ekstrak etanol $70 \%$ daun kecipir (Psophocarpus tetragonolobus (L.) DC.) mengandung senyawa metabolit sekunder flavonoid, saponin, tannin, dan steroid. Infusa daun kecipir mengandung senyawa metabolit sekunder flavonoid, saponin dan tanin.

Hasil pengujian aktivitas antioksidan ekstrak etanol $70 \%$ daun kecipir, infusa daun kecipir dan vitamin $\mathrm{C}$ berturut-turut diperoleh nilai $I C_{50}$ sebesar $22,12 \mathrm{ppm}$ (sangat kuat), 167,03 (lemah) dan 6,82 ppm (sangat kuat).

\section{DAFTAR PUSTAKA}

[1]. Ahmad,A.R., Mun'im A., dan Elya B. 2012. Study of antioxidant activity with reduction of DPPH radical and xanthin oxidase inhibitor of the extract of Ruellia Tuberosa Linn Leaf . International Research Journal Fo Pharmacy: 66.

[2]. Da’i M., Wulandari M.M., Utami W. 2011. Uji Aktivitas Penangkap Radikal DPPH Oleh Analog Kurkumin Monoketon Dan NHeteroalifatik Monoketon. Surakarta: Universitas Muhammadiyah Surakarta, Vol. 12 No. 1: 19-25.

[3]. Handayani T. 2013. KECIPIR, Potensi Lokal Yang Terpinggirkan. Bandung : IPTEK Tanaman Sayuran, No. 001: 2.
[4]. Safitri V. 2018. Uji Aktivitas Antioksidan Fase n-Hexan, Etil Asetat, dan Air Dari Ekstrak Etanol 96\% Daun Kecipir (Psophocarpus tetragonolobus (L.) [Skripsi]. Jakarta: Universitas Pancasila.

[5]. Departemen Kesehatan Republik Indonesia. 1985. Cara Pembuatan Simplisia Jakarta: Direktorat Jendral Pengawasan Obat dan Makanan. Direktorat Pengawasan Obat Tradisional: $1-2$.

[6]. Associati of Official Analytical Chemist. 2000. Official Method 942.05 Ash ofanimal feed. AOAC Official Method 4:6.

[7]. Associati of Official Analytical Chemist. 2000. Official Method 942.05 Ash ofanimal feed. AOAC Official Method 4:6.

[8]. Wahyuni S. 2010. Karakterisasi Senyawa Bioaktif Isoflavon dan Uji Aktivitas Antioksidan dari Ekstrak Tempe Berbahan Baku Buncis dan Kecipir. Surakarta : Program Pasca Sarjana Biosains Universitas Sebelas Maret.

[9]. Wahyuni S. 2010. Karakterisasi Senyawa Bioaktif Isoflavon dan Uji Aktivitas Antioksidan dari Ekstrak Tempe Berbahan Baku Buncis dan Kecipir. Surakarta : Program Pasca Sarjana Biosains Universitas Sebelas Maret.

[10]. Yuhernita dan Juniarti. 2011. Analisis Senyawa Metabolit Sekunder dari Ekstrak Metanol Daun Surian yang Berpotensi Sebagai Antioksidan. Makara, Sains. Vol. 15: 48-52.

[11].Molyneux, P. 2004. The Use of The Stable Free Radical Diphenylpicrylhydrazyl (DPPH) for Estimating Antioxidant Activity. Songklanakarin J. Sci. Technol. 26(2): 211-216

[12].Hidajat, B. 2005. Penggunaan antioksidan pada anak. Surabaya: Fakultas Kedokteran Universitas Airlangga. 